\title{
Agricultural Pesticide Use/Misuse in Sub-Sahara Africa: A Brief Overview
}

\author{
Olurominiyi 0 Ibitayo* \\ Texas Southern University, USA
}

Submission: December 02, 2017; Published: March 26, 2018

*Corresponding author: Olurominiyi O Ibitayo, Professor, Texas Southern University, Houston, Texas, USA, Tel: (713) 313-7403;

Email: ibitayo_oo@TSU.EDU

\section{Mini Review}

The need to boost agricultural productivity has prompted developing countries including sub-Sahara Africa to pursue programs such as Operation Feed the Nation (OFN) in Nigeria. The focus of such "green revolution" programs is to aggressively pursue through subsidies, tax discounts, and exemption from import tax, the use of agriculture inputs such as fertilizers and pesticides. Agricultural pesticides are designed as "poisons" to prevent or destroy any pest or weeds that may interfere with the production, processing and storage of agricultural/farming products. However, the capacity to "destroy" is not limited to the targeted products but often leads to adverse human health and environmental effects.

Agricultural pesticide poisoning in sub-Sahara Africa may be intentional or unintentional. Intentional poisoning is usually carried as suicides or homicides. Unintentional poisoning which is more predominant may be occupational, and accidental. Sources of occupational poisoning include; the lack of the use of Personal Protective Equipment (PPE) such as gloves, nose and face masks, overalls and shoes by the pesticide applicator, or the use of ineffective items such as covering the face with paper masks, and the use of leaking equipment or domestic utensils for mixing pesticides. Occupational poisoning also occurs as vendors repackage pesticides in small sachets and sell in the open market. Unintentional non-occupation poisoning includes the use of "empty" pesticide containers to store water for humans and domestic animals.

Also, pesticide poisoning may be accidental through drifts from sprayed fields, early reentry to sprayed fields, and unknowingly eating animals or crops that contain pesticide residue. Documentation include the hospitalization of a cocoa farmer's family in Southwestern Nigeria after eating vegetable undergrowth of coca trees sprayed with lindane, and the reported cases of vomiting due to the consumption of noodles that contains residues of carbofuran in Nigeria [1].
Apart from the occupational and accidental poisoning mentioned earlier some of the factors that have been identified as contributors to pesticide poisoning in sub-Sahara Africa include; the extensive lack of knowledge about the adverse effects of pesticides, and lack of regulations regarding the importation, labeling, use and disposal of pesticides, and the lack of enforcement of any existing regulations. Regarding the latter, pesticides that have banned or placed on restricted use in industrialized countries due to the pesticides' toxicities are often imported into developing countries. Moreover, the boundaries between sub-Saharan countries are porous such that pesticides banned in a country can easily be transported into that country from a neighboring country.

Recommendations include establishing public education programs emphasizing the adverse impacts of these pesticides, training and certification of pesticide applicators, and the provision of PPE free or at subsidized rates. The contention in the literature that PPE are "completely unrealistic for the hot tropical climate" especially of sub-Sahara Africa is unfounded and misleading. Sub-Sahara Africa is not monolithic either as a region or as individual countries. For example, the vegetation/ climate of Nigeria can be subdivided into at least five different zones. Also, some countries such as Kenya and Zambia are located close to the equator, yet many regions in these countries have temperate climates because of the high elevation. The temperature ranges within the regions are applicable to many industrialized countries that use PPE. Finally, it is necessary to establish and implement appropriate policies for importation, labeling, use and disposal of pesticides.

\section{References}

1. Ibitayo Olurominiyi (2007) Agricultural pesticide poisoning in Sub-Sahara Africa: Past research and future needs. In: Edward C Booking (Ed.), Trends in Hazardous Materials Research, Nova Publishers, Hauppauge, NY, USA. 


\section{Your next submission with Juniper Publishers will reach you the below assets}

- Quality Editorial service

- Swift Peer Review

- Reprints availability

- E-prints Service

- Manuscript Podcast for convenient understanding

- Global attainment for your research

- Manuscript accessibility in different formats

( Pdf, E-pub, Full Text, Audio)

- Unceasing customer service

Track the below URL for one-step submission https://juniperpublishers.com/online-submission.php 